\title{
Serum Fetuin-A and Mitral Annular Calcification As a New Predictors For Significant Coronary Artery Disease
}

\author{
Maha AF Hammoudah, Zizi Saad*, Mohamed Elrawy* \\ Medical Biochemistry and Cardiology Departments* Faculty of \\ Medicine, Menoufiya University and *Zagazig University
}

\begin{abstract}
Mitral annular calcification has been shown to be associated with atherosclerosis, and is a predictor of cardiovascular events. Fetuin-A has recently been described as a serum-based inhibitor of calcification. The present study was designed to evaluate the predictive value of serum fetuin-A and mitral annular calcification in patients with suspected/ diagnosed coronary artery disease. We prospectively studied fifty four patients with suspected/diagnosed coronary artery disease without renal impairment or rheumatic valvular disease. The patients divided into 3 groups according to fetuinA values. Group 1 low fetuin-A (32 patients). Group 2 normal fetuin-A (12 patients), group 3 fetuin-A high fetuin-A (10 patients). Full clinical examination, transthoracic echocardiography, coronary angiography, biochemical investigations offered to all patients and fetuin-A level measured using EDI human fetuin-A ELISA kit. The results of the current study showed a higher incidence of mitral annular calcification among group 1 (59.4\%) in comparison to other groups, on other hand the same group had lower left ventricular ejection fraction percent and higher incidence of resting regional wall motion abnormalities. Angiography showed a higher prevalence of severe coronary artery disease in patients with mitral annular calcification than those without. Group 1 had, also higher prevalence of left main stenosis (43.1\%vs 0\%) $P<0.05$, and triple vessels disease (43.6\%vs $13 \%) \quad P<0.05$. While the predictive ability of Mitral annular calcification in detection of significant coronary artery disease was highly significant $P=0.0001$. There was significant negative correlation between fetuin-A and hsCRP $p<0.01$ and $L D L-c p<0.05$. One of the main findings is the inverse association of serum fetuin-A concentration with Mitral annular calcification as well as strong predictive value of both to presence of significant coronary artery disease after multilogestic regression analysis. Conclusion: in symptomatic patients with suspected coronary artery disease, the presence of low fetuin-A level and mitral annular calcification, may be considered as independent predictors for the presence of significant obstructive coronary artery disease.
\end{abstract}

\section{INTRODUCTION}

Vascular calcification is common with aging, diabetes and kidney disease and is associated with increased cardiovascular morbidity. ${ }^{(\mathbf{1})}$
Mitral annular calcification (MAC) is a fibrous non-inflammatory degenerative calcification of the mitral valve ring. ${ }^{(2)}$

It was first described in 1908 by Bonninger in its association with 
complete heart block. It occurs more often in women and the elderly. ${ }^{(3)}$

MAC has been shown to be associated with atherosclerosis, and is a predictor of cardiovascular events. Risk factors vary in these patient groups, but advanced age and inflammations are commonly associated with increased vascular calcification. $^{(4)}$

MAC has been found to play a role in atrial enlargement, left ventricular enlargement, atrial fibrillation, conduction defects, mitral regurgitation, mitral stenosis, hypertrophic cardiomyopathy, and bacterial endocarditis. ${ }^{(5)}$

Until recently, vascular calcification in the context of a mineral imbalance was considered to be an unregulated consequence of the deposition of insoluble basic calciumphosphate (BCP; mixture of octacalcium phosphate, dicalcium phosphate dihyderate, and apatite) mineral in the extracellular matrix occurring when concentration of $\mathrm{Ca}$ and Phosphate ions in the local environment/circulation exceeded the solubility product for calcium phosphate. ${ }^{(6)}$

Fetuin-A (alpha-2-Heremans Schmid glycoprotein) is produced during fetal development by multiple tissues, whereas in adults it is synthesized predominantly by the liver. ${ }^{(7)}$ It is a member of the cystatin super-family of cysteine protease inhibitors. Fetuin-A constitutes the largest $\alpha 2-$ band in serum electrophoresis. Its normal serum concentration amounts to 0.5 to $1 \mathrm{~g} / \mathrm{L}$, and it is down-regulated under conditions of inflammation. ${ }^{(8)}$ FetuinA has recently been described as a serum-based inhibitor of calcification. ${ }^{(9)}$ In vitro studies demonstrate that fetuin-A forms a complex with calcium and phosphorus and increases their solubility in a manner reminiscent of the mean by which apolipoproteins solubilize lipids. ${ }^{(10)}$

Among persons with end-stage renal disease, lower fetuin-A concentrations are associated with more extensive vascular calcification in cross-sectional analyses and with increased cardiovascular events and all-cause mortality longitudinally. $\mathbf{( 1 1 , 1 2 )}$ Besides playing a pivotal role in the inhibition of $\mathrm{Ca} \times \mathrm{P}$ precipitation, fetuin-A exhibits additional antiinflammatory and phagocytosispromoting activity. ${ }^{(8)}$ Nearly few is known about fetuin-A serum levels in non renal patients with mitral annular calcification. ${ }^{(13)}$

The aim of the present study was designed to evaluate the predictive value of serum fetuin-A concentration and mitral annular calcification (MAC) in patients with suspected/diagnosed coronary artery disease.

\section{SUBJECTS \& METHODS}

Fifty four consecutive patients with suspected $\backslash$ diagnosed coronary artery disease were evaluated in Aseer Central Hospital, Abha, Kingdom of Saudi Arabia from December 2007 to November 2008 .

All participants were recruited from Emergency Department or Out Patient Clinics if they met one of the following inclusion criteria:

- Admission as a case of acute coronary syndrome. 
- History of old myocardial infarction.

- Previous angiographic evidence of $\geq 70 \%$ stenosis in $\geq 1$ coronary vessels.

- Evidence of exercise induced ischemia by treadmill or other stress tests.

- History of coronary revascularization.

Those with rheumatic valvular disease, cardiomyopathy or prosthetic valves, also patients aged $>60$ years and those with chronic or acute renal disease were excluded.

The patients were divided into 3 groups according to fetuin-A values:

Group 1: fetuin-A $\leq 0.59 \mathrm{~g} / 1$ included 32 patients.

Group 2: fetuin-A 0.6-0.9g/1 included 12 patients.

Group 3: fetuin-A $\geq 0.95 \mathrm{~g} / 1$ included 10 patients.

All included patients under went baseline study; full history taking, physical examination, resting echocardiogram, coronary angiography, laboratory

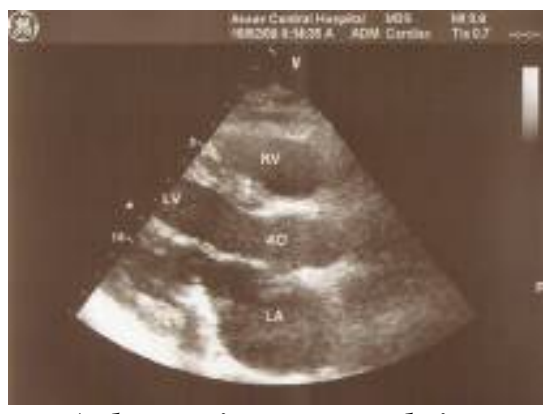

A- long axis parasternal view measurements that included serum fetuin-A level, hsCRP, Lipid profile, serum calcium, serum phosphorus, and creatinine clearance. All clinical, echocardiographic, coronary angiographic as well as laboratory data were collected prospectively.

Echocardiographic examinations:

All study participants underwent echocardiography with complete two dimensional and Doppler color flow examinations with obtaining all standards views. 2.5-MHZ transducer of vivid 7 phased array sector scanner was used.

Echocardiography done to asses left ventricular function, resting regional wall motion abnormalities $\left(\mathrm{RWMA}_{\mathrm{S}}\right)$ as well as determining the presence of mitral annular calcification. Mitral annular calcification was defined by an echodense structure located at the junction of the atrio ventricular groove and the posterior mitral leaflet on the parasternal long-axis, apical 4chamber or parasternal short axis views. $^{(14)}$ (figure1 A\&B).

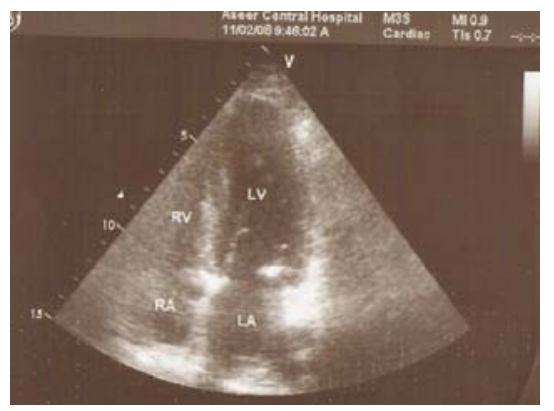

B-Apical 4 chambers view

Figure 1 A \& B: Cross sectional echocardiography of patients with mitral annular calcification; showing the presence of an intense echo producing structure located at the junction of the atrio-ventricular groove and posterior mitral valve leaflet. 


\section{Coronary Angiography}

The presence of coronary artery disease was determined by coronary angiography, cardiologist trained in coronary angiography and unaware of the echocardiogrpahic results operated and interpreted the angiographic

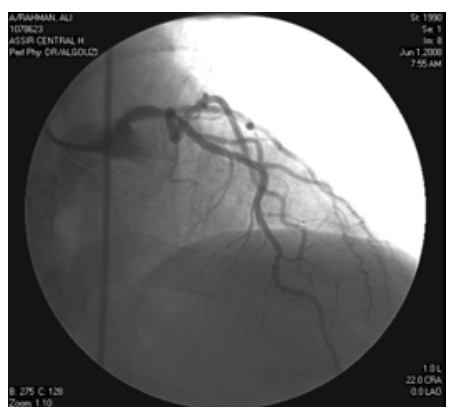

Distal left main coronary artery stenosis

Biochemical investigation:

Kidney function was determined by estimated glomerular filtration rate $=186 \mathrm{x} \quad$ (serum creatinine $^{-}$ $\left.{ }^{1.154}\right) \times\left(\right.$ age $\left.^{-0.203}\right) \times(0.742$ if female $) .^{(16)}$

Fasting 12 hours blood sample were obtained and serum separated by centrifugation $(850-1500 \mathrm{Xg}$ for 10 min.). Serum samples were stored frozen at $-20^{\circ} \mathrm{C}$, to measure Fetuin-A, cardiophase hsCRP, calcium, phosphorus, total cholesterol, highdensity lipoprotein cholesterol, and triglyceride levels using Daimension RXL Max clinical chemistry system (Dade Behring USA) . Low-density lipoprotein cholesterol concentrations were estimated by the Friedewald equation. ${ }^{(17)}$

\section{Serum fetuin-A:}

Serum fetuin-A was measured by using EDI human fetuin-A ELISA kit studies visually, significant coronary artery disease was defined as any stenosis of $>70 \%$ in at least one major epicardial coronary artery or $>50 \%$ in the left main coronary artery. ${ }^{(\mathbf{1 5})}$ (figure2 A\&B).

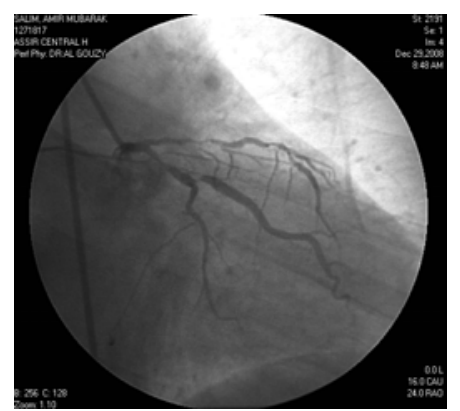

Triple vessels coronary artery stenosis

(Epitope Diagnostic, Inc., USA). That ELISA kit is designed, developed and produced for quantitative measurement of human fetuin-A in serum sample. The assay utilizes the two-site sandwich technique with two selected goat antihuman fetuin-A polycolonal antibodies that bind to different epitopes of human fetuin-A. The concentration of human fetuin-A in test samples were determined directly from standard curve. The intra and inter assay coefficients of variation are $4.5 \%$ and $5.7 \%$ respectively. The assay range 0.05 $3.5 \mathrm{~g} / \mathrm{L}$. the expected values 0.35 $0.95 \mathrm{~g} / \mathrm{L}$ mean $0.57 \pm 0.13 \mathrm{SD}^{\left({ }^{(18)}\right.}$

\section{Cardiophase hsCRP:}

Cardiophase hsCRP is an in vitro diagnostic reagent for the quantitative determination of C-reactive protein in human serum by means of particle 
enhanced immunonephlometery using BNIII system (Dade Behring, USA). The principle of the method; polystyrene particles coated with monocolonal antibodies specific to human CRP are aggregated when mixed with samples containing CRP. These aggregates scatter a beam of light passed through the sample. The intensity of the scattered light is proportional to the concentration of the relevant protein in the sample. The result is evaluated by comparison with a standard of known . ${ }^{(19)}$

\section{Serum Calcium:}

The method is modification of the calcium O-cresolphethalien complexone (OCPC) reaction. ${ }^{(20)}$

\section{Serum Phosphorus:}

The method is a modification of the classical phosphomolybdate method, uses a mixture of of $\mathrm{p}$ methylaminophenol sulfate and bisulfite to reduce the phophomolybdate. The phosphorus method measures the absorption of the reduced phosphomolybdate. ${ }^{(21)}$

\section{Statistical methods:}

All data were collected, summarized, presented and analyzed by using an appropriate Statistical package program (SPSS version, 13). Quantitive data which are normally distributed were summarized by mean and standard deviation. Qualitative data are summarized by number and percentage. Test of significance for qualitative data are chi square. Test of significance for quantitative data which are normally distributed for 2 groups are $\mathrm{t}$ test, for more than 3 groups are F (ANOVA) test and post hoc test to determine difference among groups. Pearson correlation coefficient among 2 continuous quantitative variable. All statistical tests were considered significant at $\mathrm{P}<0.05$.

\section{RESULTS}

Fifty four patients with suspected/ diagnosed CAD were enrolled in the present study. Patients were divided into 3 groups according to fetuin-A values $\quad(l o w \leq 0.59 \mathrm{~g} / 1$, within normal $0.6-0.9 \mathrm{~g} / \mathrm{l}$ and high $\geq 0.95 \mathrm{~g} / \mathrm{l})$. There was no intergroup difference as regards age and gender; the mean age was $51 \pm 3$ years age. The gender in groups 1,2 , and 3 were $(50 \%$ male, $50 \%$ female, $41.6 \%$ male, $58.4 \%$ female and $40 \%$ male, $60 \%$ female respectively). There was no statistical significant difference among studied groups regarding to past history of risk factors such as, diabetes mellitus, hypertension, as well as history of coronary artery disease $(\mathrm{P}>0.05)$ table 1

Echocardiographic findings: among studied groups (table 2). The incidence of MAC was greatest among group1 patients; 19 patients out of 32 had MAC, while only 4 patients in group2 and 3 (2patients/each group) proved to have MAC and $P$ value was highly significant $\mathrm{P}<0.05$. Figure (3) illustrated the prevalence of MAC among different levels of fetuin-A group 1(59.4\%), group 2 was $(16.7 \%)$ and the presence in group $3(20 \%)$. The difference in between was statistically significant $\mathrm{P}<0.05$. The $\mathrm{EF} \%$ was $\quad(53.9-58 \%, \quad 58 \%-60 \%$, $>60 \%$ ) in groups $1,2,3$ respectively with statistically significant difference $\mathrm{P}<0.05$. The presence of resting regional wall motion abnormalities 
was significantly higher in group 1; $21(65.6 \%)$ patients, in comparison to $25 \%$ of patients in group 2 with RWMAs while only $10 \%$ of patient in group 3 ( $\mathrm{P}$ value highly significant $<0.01)$

The angiographic findings: in patients with and without MAC table (3). We found significantly more obstructive coronary artery disease in patients with MAC than those without MAC as shown in table 3, patients with MAC had higher prevalence of significant left main coronary artery stenosis $(13.1 \%$ vs. 0\%) and higher prevalence of triple vessel coronary artery disease (43.6\% vs. $13 \%)$. Single vessel coronary artery disease was higher in the group without MAC in comparison to other group with MAC. The prevalence of double vessel disease showed no statistical significant difference between the two groups $(\mathrm{P}>0.05)$.

Laboratory findings: in the studied three groups with different levels of fetuin-A table (4). Statistical comparison of hsCRP values between all groups show highly significant difference ( $p$ value $<0.01$ ). As well as intergroup difference regarding cholesterol, LDL-c, HDL-c and triglyceride showed significant difference ( $\mathrm{P}$ value $<0.05)$. Creatinine clearance, calcium and phosphorus showed non significant difference between all groups $(\mathrm{P}>0.05)$. When we studied correlation between studied parameters and fetuin-A value among all patients, there were highly significant negative correlation between fetuin-A and hsCRP ( $\mathrm{r}=$ $0.717 \mathrm{P}<0.01)$. Significant negative correlation between fetuin-A and LDL-c, while cholesterol, calcium, phosphorus, creatinine clearance showed statistically non significant correlation $(\mathrm{P}>0.05)$.

After multivariate logistic regression analysis table(5), MAC and fetuin-A were found to be the main independent predictors for the presence of significant coronary artery disease; significance for MAC was 0.0001 , and fetuin-A was 0.0019, while dyslipidemia, diabetes mellitus and age were non-significant.

The prevalence of coronary artery disease after cardiac catheterization among different studied group with different levels of fetuin-A were shown in figure (4). We found significantly higher incidence of obstructive coronary artery disease among patients with low fetuin-A in comparison to other groups. The prevalence percentage was $(37 \%, 7 \%$, $9 \%$ ) in groups $1,2,3$ respectively. 
Table (1) Demographic Data of studied groups

\begin{tabular}{|c|c|c|c|c|c|}
\hline Variables & Group (1) & Group (2) & Group (3) & $\begin{array}{c}\text { Annova } \\
\text { F test }\end{array}$ & $\begin{array}{c}\mathbf{P}- \\
\text { value }\end{array}$ \\
\hline \multirow[b]{2}{*}{ Age (Years) } & Mean + SD & Mean + SD & Mean + SD & \multirow[b]{2}{*}{0.134} & $\mathrm{P}>0.05$ \\
\hline & $51.5 \pm 3.1$ & $51.8 \pm 3.9$ & $51.1 \pm 3.07$ & & $\begin{array}{l}\mathrm{P} 1>0.05 \\
\mathrm{P} 2>0.05 \\
\mathrm{P} 3>0.05\end{array}$ \\
\hline \multicolumn{6}{|l|}{ Gender } \\
\hline Male (\%) & $50 \%$ & $\begin{array}{lll}5 & 41.6 \% \\
\end{array}$ & $40 \%$ & \multirow{2}{*}{0.439} & \multirow[t]{2}{*}{$\mathrm{P}>0.05$} \\
\hline Female $(\%)$ & $50 \%$ & $58.4 \%$ & $60 \%$ & & \\
\hline \multicolumn{4}{|l|}{ Clinical data } & $\begin{array}{l}\text { Chi } \\
\text { square }\end{array}$ & $\mathrm{P}$ value \\
\hline Diabetes mellitus & $\%$ & $\%$ & $\%$ & \multirow[b]{2}{*}{3.1} & \multirow[b]{2}{*}{$\mathrm{P}>0.05$} \\
\hline$+\mathrm{ve}$ & $68.7 \%$ & $50 \%$ & $40 \%$ & & \\
\hline Hypertension & $\%$ & $\%$ & $\%$ & \multirow[b]{2}{*}{5.4} & \multirow[b]{2}{*}{$\mathrm{P}>0.05$} \\
\hline$+\mathrm{ve}$ & $53 \%$ & $50 \%$ & $30 \%$ & & \\
\hline History of CAD & $\%$ & $\mathrm{~N}$ & $\%$ & \multirow[b]{2}{*}{5.4} & \multirow[b]{2}{*}{$\mathrm{P}>0.05$} \\
\hline$+\mathrm{ve}$ & $37.5 \%$ & $8.3 \%$ & $10 \%$ & & \\
\hline
\end{tabular}

$C A D$ : coronary artery disease

$P 1=$ group 1 vs. group 2, $\quad P 2=$ group 1 vs. group $3 \quad, P 3=$ group 2 vs. group 3. $p>0.05=$ statistically non significant $\quad P<0.05=$ statistically significant

Table (2) Echocardiographic findings among studied groups

\begin{tabular}{|c|c|c|c|c|c|}
\hline & Group (1) & Group (2) & Group (3) & $\begin{array}{c}\text { Chi } \\
\text { square }\end{array}$ & $\begin{array}{c}P- \\
\text { value }\end{array}$ \\
\hline MAC & $\%$ & $\mathrm{~N} \quad \%$ & $\%$ & \multirow[b]{2}{*}{9.0} & \multirow[t]{2}{*}{$\mathrm{P}<0.05$} \\
\hline$+\mathrm{ve}$ & $\begin{array}{ll}19 & 59.4 \\
\end{array}$ & $2 \quad 16.7 \%$ & $2 \quad 20 \%$ & & \\
\hline $\mathrm{EF}$ & $53.9-58 \%$ & $58-60 \%$ & $>60 \%$ & 2.5 & $\mathrm{P}<0.05$ \\
\hline RWM & $\%$ & $\%$ & $\mathrm{~N}$ & \multirow{2}{*}{12.2} & $\mathrm{P}$ \\
\hline$+\mathrm{ve}$ & $21 \quad 65.6 \%$ & $25 \%$ & $10 \%$ & & $<0.01$ \\
\hline
\end{tabular}

MAC: mitral annular calcification.

LVEF\%: left ventricular ejection fraction percentage.

RRWMAs: Resting Regional Wall Motion abnormalities.

+ve : present or detected 
Table (3): Angiographic findings in patients with and without MAC

\begin{tabular}{|c|c|c|c|c|c|c|}
\hline & \multicolumn{2}{|c|}{$\begin{array}{c}\text { Group (1) } \\
\text { With MAC } \\
\quad \mathrm{N}=\mathbf{2 3}\end{array}$} & \multicolumn{2}{|c|}{$\begin{array}{c}\text { Group (2) } \\
\text { Without MAC } \\
\quad \mathbf{N}=\mathbf{3 1} \\
\end{array}$} & $\begin{array}{c}\text { Chi } \\
\text { square }\end{array}$ & $\begin{array}{c}\mathbf{P}- \\
\text { value }\end{array}$ \\
\hline LM & $\mathrm{N}$ & $\%$ & $\mathrm{~N}$ & $\%$ & \multirow{2}{*}{4.2} & \multirow{2}{*}{$\mathrm{P}<0.05$} \\
\hline$+\mathrm{ve}$ & 3 & $13.1 \%$ & 0 & $0 \%$ & & \\
\hline TVD & $\mathrm{N}$ & $\%$ & $\mathrm{~N}$ & $\%$ & \multirow{2}{*}{6.4} & \multirow[t]{2}{*}{$\mathrm{P}<0.05$} \\
\hline$+\mathrm{ve}$ & 10 & $43.6 \%$ & 4 & $13 \%$ & & \\
\hline DVD & $\mathrm{N}$ & $\%$ & $\mathrm{~N}$ & $\%$ & \multirow{2}{*}{0.88} & \multirow[t]{2}{*}{$\mathrm{P}>0.05$} \\
\hline$+\mathrm{ve}$ & 7 & $30.4 \%$ & 6 & $9.4 \%$ & & \\
\hline SVD & $\mathrm{N}$ & $\%$ & $\mathrm{~N}$ & $\%$ & \multirow{2}{*}{4.5} & \multirow[t]{2}{*}{$\mathrm{P}<0.05$} \\
\hline$+\mathrm{ve}$ & 1 & $13.1 \%$ & 7 & $22.5 \%$ & & \\
\hline
\end{tabular}

LM: left main coronary artery

DVD: Double vessel Disease.

TVD: Triple vessel disease.

$+v e$ : present or detected

SVD single vessel disease.

Table (4): Comparison between studied groups as regard laboratory results

\begin{tabular}{|c|c|c|c|c|c|}
\hline Variables & $\begin{array}{c}\text { Group (1) } \\
\mathbf{N}=\mathbf{3 2} \\
\text { Mean } \pm \text { SD }\end{array}$ & $\begin{array}{c}\text { Group (2) } \\
\mathbf{N = 1 2} \\
\text { Mean } \pm \text { SD }\end{array}$ & $\begin{array}{c}\text { Group (3) } \\
\mathbf{N = 1 0} \\
\text { Mean } \pm \text { SD }\end{array}$ & ANOVA & $\begin{array}{c}\text { P- } \\
\text { value }\end{array}$ \\
\hline Fetuin-A g/l & $0.535 \pm 0.03$ & $0.72 \pm 0.14$ & $1.0 \pm 0.08$ & 12.98 & $\mathrm{P}<0.01$ \\
\hline hsCRP mg/l & $\begin{array}{c}6.5 \pm 2.8 \\
\text { Median 6.2 }\end{array}$ & $\begin{array}{c}4.7 \pm 2.4 \\
\text { median 4.7 }\end{array}$ & $\begin{array}{c}2.6 \pm 1.07 \\
\text { median 2.9 }\end{array}$ & 9.4 & $\mathrm{P}<0.01$ \\
\hline $\begin{array}{c}\text { Cr clearance } \\
\text { GFR,mL.min }{ }^{-1} .1 .73\end{array}$ & $81.1 \pm 6.7$ & $80.7 \pm 5.4$ & $83.6 \pm 6.3$ & 0.670 & $\mathrm{p}>0.05$ \\
\hline $\begin{array}{c}\text { Cholesterol } \\
\text { mg/dl }\end{array}$ & $202.6 \pm 15.6$ & $214 \pm 12.2$ & $193.6 \pm 17.8$ & 4.9 & $\mathrm{p}<0.05$ \\
\hline LDL-C mg/dl & $130 \pm 20.3$ & $114.9 \pm 13.8$ & $113.4 \pm 13.9$ & 4.9 & $\mathrm{P}<0.05$ \\
\hline HDL-c mg/dl & $43.3 \pm 6.4$ & $47.5 \pm 7.5$ & $48.8 \pm 6.3$ & 3.4 & $\mathrm{P}<0.05$ \\
\hline Triglyceride mg/dl & $170.6 \pm 10.4$ & $191 \pm 13.6$ & $181.9 \pm 21.1$ & 10.7 & $\mathrm{p}<0.01$ \\
\hline Calcium mg/dl & $9.6 \pm 0.42$ & $9.4 \pm 0.48$ & $9.6 \pm 0.46$ & 1.3 & $\mathrm{p}>0.05$ \\
\hline Phosphors mg/dl & $3.7 \pm 0.48$ & $3.9 \pm 0.29$ & $3.8 \pm 0.20$ & 0.692 & $\mathrm{p}>0.05$ \\
\hline
\end{tabular}

hsCRP: high sensitive $C$ reactive protein.

$L D L-c$ : low density lipoprotein cholesterol.

$H D L-c$ : high density lipoprotein cholesterol. 
Table (5): Correlation between Fetuin-A with hsCRP, Chol, CRP, calcium, phosphorus, age and creatinine clearance among patients

\begin{tabular}{|c|c|c|}
\hline Variables & (r) value & P value \\
\hline hs CRP & -0.717 & $\mathrm{P}<0.01$ \\
\hline Cholesterol & -0.221 & $\mathrm{P}>0.05$ \\
\hline LDL-c & -0.396 & $\mathrm{P}<0.05$ \\
\hline Calcium & -0.026 & $\mathrm{P}>0.05$ \\
\hline Phosphorus & 0.062 & $\mathrm{P}>0.05$ \\
\hline Age & -0.071 & $\mathrm{P}>0.05$ \\
\hline Creatinine clearance & 0.050 & $\mathrm{P}>0.05$ \\
\hline
\end{tabular}

hsCRP: high sensitive $C$ reactive protein. $\quad P<0.05$ significant

LDL-c : low density lipoprotein cholesterol. $\quad P>0.05$ non significant

Table (6): Multivariate analysis (logistic regression model) as regard predictors of CAD

\begin{tabular}{|l|c|c|c|c|c|c|c|}
\hline Variable & Score & DF & B & Wald & SE & Sign. & R \\
\hline MAC & 12.3 & 1 & 5.1 & 42.4 & 0.792 & 0.0001 & 0.712 \\
\hline Fetuin-A & 10.2 & 1 & 4.1 & 39.2 & 0.542 & 0.0019 & 0.689 \\
\hline Dyslipidemia & 4.1 & 1 & 2.4 & 21.4 & 0.492 & 0.0435 & 0.522 \\
\hline DM & 3.9 & 1 & 1.9 & 17.5 & 0.356 & 0.0447 & 0.498 \\
\hline Age & 2.2 & 1 & 1.6 & 15.2 & 0.256 & 0.1189 & 0.321 \\
\hline Gender & 1.2 & 1 & 1.1 & 12.3 & 0.245 & 0.4175 & 0.245 \\
\hline
\end{tabular}

MAC: Mitral annular calcification.

DM: diabetes mellitus 


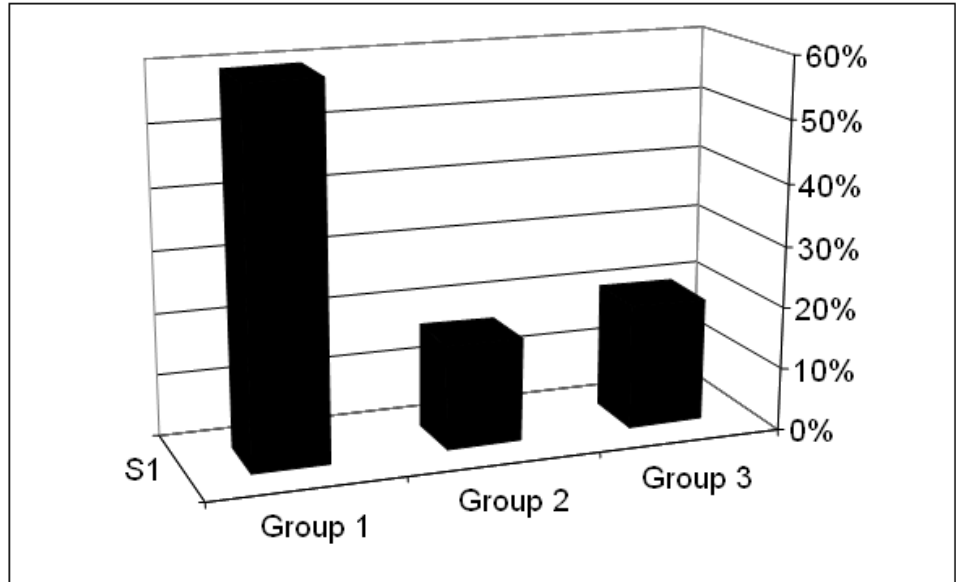

Figure (3): Prevalence of MAC among studied groups with different levels of fetuin-A

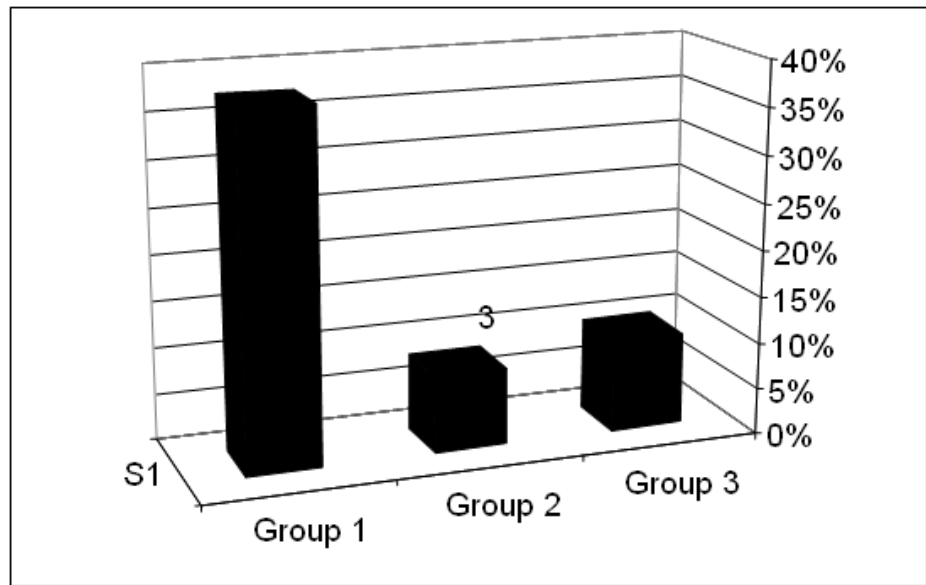

Figure (4): Prevalence of coronary heart disease among studied groups with different levels of fetuin-A

\section{DISCUSSION}

The serum fetuin-A is a potent systemic inhibitor of soft tissue calcification, fetuin-A is highly effective in the formation and stabilization of protein-mineral colloid, referred to as calciprotein particles (CPP). Albumin and acidic protein in general greatly enhanced the fetuin-A triggered formation of secondary CPPs and this substituted substantial amounts of fetuin-A without loss of inhibition of calcium phosphate precipitation. ${ }^{(22)}$ 
Prior epidemiological studies evaluating the association of fetuin-A with dystrophic calcification have largely been limited to populations with end-stage renal disease in which lower fetuin-A concentration are associated with vascular and valvular calcification. ${ }^{(\mathbf{2 3 , 2 4})} \quad$ Nearly few is known about fetuin-A serum level in non renal patients. ${ }^{(13)}$

Mitral annular calcification is a fibrous, degenerative calcification of the mitral valve support ring and it has been shown to be associated with atherosclerosis. ${ }^{(25)}$ A prior prospective investigation from the Framingham heart study, MAC was independently associated with stroke. ${ }^{(15)}$ and cardiovascular events. (26)

Experimentally induced systemic arterial atherosclerosis is associated with the deposition of fatty plaques on the ventricular surface of the posterior mitral leaflet. ${ }^{(27)}$ These findings suggest that coronary atherosclerosis and MAC have a similar etiology.

Here in the present study we evaluate the serum fetuin-A concentration and mitral annular calcification as a predictors for significant coronary artery disease in patients with suspected/diagnosed coronary artery disease (with no renal impairment). Importantly the current studied groups were matched regarding age, gender and clinical history of diabetes and hypertension in order to element any errors during evaluation of MAC and fetuin $-\mathrm{A}$ as predictors for significant CAD.

One of the main results of the present study was that we demonstrate an inverse association of serum fetuinA concentration with MAC among those patients either suspected /diagnosed CAD. Also, a strong association was observed between low fetuin-A level and prevalence of significant CAD. These finding are consistent to some degree with the results of Ix et al.(2007) ${ }^{(11)}$ who stated that fetuin-A may represent an important inhibitor of dystrophic calcification in persons with coronary artery disease.

In the present study we find that fetuin-A is inversely correlated with hs-CRP in all studied groups. These findings are consistent with results found by Kuznair et al. ${ }^{(9)}$ and Ix et al. ${ }^{(11)}$ Despite the fact that fetuin-A is an acute phase reactant, Stenvinkil et al. ${ }^{(28)}$ demonstrated an inverse correlation between serum fetuin-A and CRP in hemodialysed patients. Similar results has also been reported by Ketteler et al. ${ }^{(23)}$. Furthermore, low fetuin-A levels were associated with increased cardiovascular mortality. Serum from dialysis patients with calcific uremic arteriopathy had impaired ex vivo capacity to inhibit hydroxyapatite precipitation, which could be normalized by the addition of purified fetuin-A. ${ }^{(\mathbf{1 8})}$ Also, an inverse correlation between fetuin-A level and low-density lipoprotein as risk factor for dystrophic calcification, which is in agreement with that obtained by Ix et al., 2007. (11) As regards to serum phosphorus we found no correlation with fetuin-A which is consistent with that found by Chen et al. 2007. ${ }^{(29)}$ They found ${ }^{125}$ I-labeled fetuin-A coprecipitated in mixtures of calcium and phosphate and in mixtures of calcium and carbonate, but not in mixtures of magnesium and phosphate, indicating that the binding of fetuin-A to hydroxyapatite is due to 
interaction with calcium ions rather than phosphate ions.

As regard to the prseent Echocardiographic findings, the group of patients with MAC and low fetuinA level had the lowest $\mathrm{EF} \%$ in comparison to other groups, as well as the incidence of resting RWMAs was higher in same group indicating a significant myocardial ischemia in those patients, these findings were in agreement with previous studies. ${ }^{\text {(25) }}$

Boon and his colleagues ${ }^{(30)}$ found an association of MAC with age and vascular risk factors (age, female sex, hypertension, diabetes mellitus and hypercholesterolemia). Thus, a significant association of MAC with known major risk factors for CAD may partly explain the association of MAC with obstructive CAD on angiography in the present study.

One of the main finding of the current study is that mitral annular calcification is an independent predictor of the presence of severe stenosis ( $\geq 70 \%$ diameter stenosis) in at least one major epicardial coronary artery in patients presenting with chest pain. Moreover, mitral annular calcification is an indicator of a higher prevalence of triple vessel disease or significant left main coronary artery stenosis in our patients groups especially when associated with low fetuin-A level.

Angiographic finding in the present study were similar to those reported by Atar and his colleagues $^{(15)}$, both studies showed that MAC is a marker and dependent predictor for presence of significant CAD, where our study showed that patients group with MAC owing a great prevalence of LM \& TVD coronary lesions in comparison to those patients with no MAC.

Therefore, we considered that, the unique finding of our study was the triple arms results of association between the presence of mitral annular calcification, low fetuin-A level and significant coronary artery disease .

Conclusion and clinical implications

The detection of mitral annular calcification by simple non invasive imaging method as transthoracic echocardiolgraphy in association with low fetuin-A level, may be considered as independent predictors for the presence of significant obstructive coronary artery disease. Therefore, in symptomatic patients with suspected $\mathrm{CAD}$, the presence of MAC and low fetuin-A level may support the need for an invasive evaluation of the patient's complaints with aggressive modification of risk factors.

\section{REFERENCES}

1. Giachelli CM. (2004): Vascular calcification mechanism. J Am Soc Nephrol. ,15: 2959-2964.

2. D'Cruz I, Panetta F Cohen H (1979): Submitral calcification or sclerosis in elderly patients. Mmode and two- dimensional echocardiography in" Mitral annulus Calcification". Am J Cardiol., 44:31-38.

3. Savage DD, Garrison RJ, Castelli WP, Mc Namara PM, Anderson SJ (1983): Prevalance of submitral (annular) calcium and its correlates in a general population-based sample (the Framigham study). Am J Cardiol., 51:1375-1378. 
4. Bozbas H, Pirat B, Yildirir A, Simsek V, Sade E, Altin C, Muderrisonglu H (2008): Mitral annular calcification associated with impaired coronary microvescular function. Atherosclerosis, 168(1):115-121.

5. Nair CK, Thomson W, Ryschon K, Kook C, Hee TT, Sketch MH (1989): Long term follow-up of patients with echocardiogaphically detected mitral annulus calcium and comparison with age and sexmatched control subjects. Am J Cardiol., 63: 465- 470.

6. Reynolds JL, Skepper JN, Mc Nair N, Kasama T, Gupta K, Weissberg PL, Jahnen- Dechent W, and Shanahan CM. (2005): Multifunctional roles for serum protein fetuin-A in inhibition of human vascular smooth muscle cell calcification. J Am Soc Nephrol., 16:2920-2930.

7. Moe SM, and Chen NX (2004): Pathphysiology of vascular calcification in chronic kidney disease. Circulation Research 95:560.

8. Küzniar J, Porazko T, Klinger M, (2008): Relationship between Fetuin-A concentration, elvated level of inflammatory markers and arterial wall stiffness in end stage kidney disease. Journal of Renal Nutrition 18 : 83-86.

9. Ix JH, Chertow GM, Shilpak MG, Brandenburg VM, Ketteler M, Whooley MA (2006): Fetuin $-\mathrm{A}$ and kidney function in persons with coronary artery disease: data from the heart and soul study. Nephrol Dial Transplant., 21 : 2144- 2151.
10. Heiss A, Duchesne A, Denecke B (2003): Structural basis of calcification inhibition by alpha 2 - HS glycoprotein/ Fetuin- A. formation of colloidal caliprotein particles . J Biochem 278: 1333313341.

11. Ix JH, Chertow GM, Shilpak MG, Brandenburg VM, ketteler M, Whooley MA (2007): Association of fetuin-A with mitral annular calcification and aortic stenosis among persons with coronary heart disease: data from the heart and soul study. Circulation 19: 2533-2539.

12. Moe SM, Reslerova M, Ketteler M, O'Neill K, Duan D, Koczman J, Westenfeld R, Jahnen-Dechent W, Chen NX, (2005): Role of calcification inhibitors in the pathogenesis of vascular calcification in chronic kidney diseases (CKD) . Kidney Int., 67: 2295-2304.

13. Kaden JJ, Reinohl JO, Blesch B, Haghi D, (2007): Systemic and local levels of Fetuin-A in calcific aortic valve stenosis. Int. J. Mol. Med., 20 (2):193-197.

14. Barasch E, Gottdiener JS, Larsen EK, Chaves PH, Newman AB, Manolio TA. (2006): Clinical significance of calcification of the fibrous skeleton of the heart and atherosclerosis in community dwelling elderly: the cardiovascular health study (CHS). Am Heart J.;151:39-47.

15. Atar S, Jeon DS, Luo H, Siegel R (2003): Mitral annular calcification: a marker of severe coronary artery disease in patients 
under 65 years old. Heart; 89:161-164.

16. Levey AS, Bosch JP, Lewis JB, Greene T, Rogers N, Roth DC, (1999): A more accurate method to estimate glomerular filtration rate from serum creatinine: a new prediction equation modification of diet in renal disease study group. Ann. Intern. Med., 130: 461-470.

17. Friedwald WT, Levy RI, Fredrickson DS (1972): Estimation of concentration of low- density lipoprotein cholesterol in plasma, without use of the preparative ultracentrifugation. Clin Chem; 18: 499- 502.

18. Schäfer C, Heiss A, Schwarz A, Westenfeld R, Ketteler $M$, Floege J, Muller-Esterl W, Schinke T, Jahnen- Dechent W(2003): The serum protein alpha 2Hermans-schmid glycoprotein/fetuin-A is a systemically acting inhibitor of ectopic calcification. J. Clin. Invest., 112:357-366.

19. Whicher JT, Ritchi RF, Johnson AM, (1994): New international reference preparation for proteins in human serum (RPPHS). Clin. Chem., 40:934-938.

20. Stern J, Lewis WHP (1957): The colorimetric estimation of calcium in serum with $\mathrm{O}$ cresolphtalein complex, Clin. Chim. Acta., 1957;2:5

21. Drewes p (1972): Direct colorimeteric determination of phosphorus in serum and urine. Clin Chim Acta, 39:81.
22. Heiss A, Eckert T, Aretz A, Richtering W, van Dorp W, Schfer c, (2008): Hierarchical role of fetuin-A and acidic serum proteins in the formation and stabilization of calcium phosphate particles. J Bio Chem ., 257: 1245-1255.

23. Ketteler $M$, Bongartz $P$, Westenfeld $R \quad$ (2003): Association of low fetuin-A (AHSG) concentration in serum with cardiovascular mortality in patients on dialysis across sectional study. Lancet 361: 827833.

24. Wang AY, Lam CW, Wang M, Chan IH, Yu CM, Lui SF, Sanderson JE. (2008): Increased circulating Inflammatory protein predict a worse prognosis with valvular calcification in end stage renal disease: A prospective cohort study. Am J Nephrol., 22;28 (4): 647-653.

25. Willens HI, Chirinos JA, Schob A (2006): The relation between mitral annular calcification and mortality in patients undergoing diagnostic coronary angiography. Echocardiography; 23 (9): 717 220.

26. Caroline S, Ramachandra S, Christropher J (2003): Mitral annular calcification: predicts cardiovascular morbidity and mortality, the framinghan heart study. Circulation, 107:14921496.

27. Trubuikar NJ, Deck JD, Aduad J (1985): Intramural stress as a causative factor in atherosclerotic lesions of the aortic valve. Atherosclerosis, 55: 299- 311. 
28. StenVinkel P, Wang K, Qureshi AR, Axelsson J, Pecoits-Filho R, Geo P, Barany P, Jogestrand T, Heimobrger $\mathbf{O}$, Holmes $\mathrm{C}$, Schalling $\mathbf{M}$, Nordfors $\mathbf{L}$, (2005): Low fetuin-A levels are associated with cardiovascular death: impact of variations in the gene encoding fetuin. Kidney int., 67: 2383- 2392.

29. Chen NX, O'Naill KD, Chen $X$, Duan D, Wang E, Stuek MS,
Edwards JM, Moe SM, (2007):

Fetuin-A uptake in bovine vascular smooth muscle cells is calcium dependent and mediated by Annexiens. Am J Physiol Renal Physiol., 292: 599- 606.

30. Boon A, Cheriex E, Lodder J. (1997): Cardiac valve calcification characteristics of patients with calcification of mitral annulus or aortic valve. Heart, 78:4724. 


\section{فوتين-أ الموجود في المصل و التكلس الحلقي الميترالي مؤشران جديدان

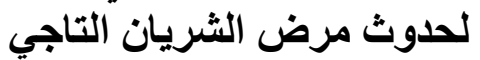

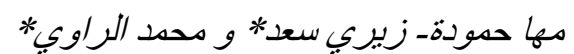

قسم الكيمباء الحيويه كليه طب شبين الكوم- قسم القلب و الأو عيه الذمويه كليه طب الزقازيق

لقد وجد أن التكلس الحلقي الميتر الي مرتبط بتصلب الثرايين و يعتبر كمؤشر لحدوث النوبات القلبية. اكتثف

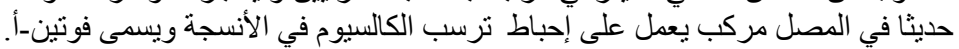

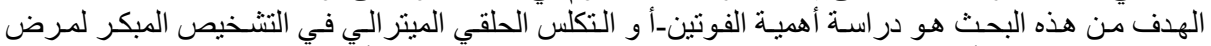

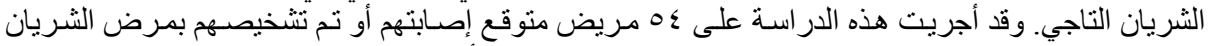

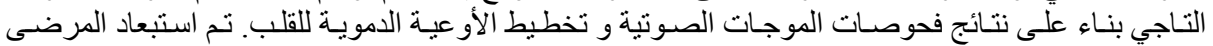

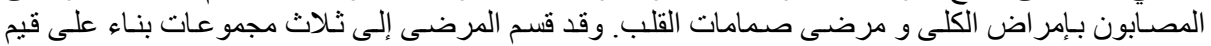

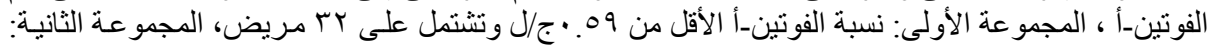

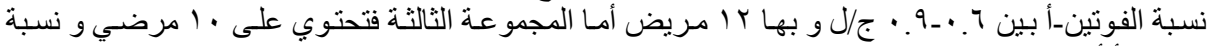

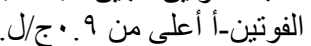

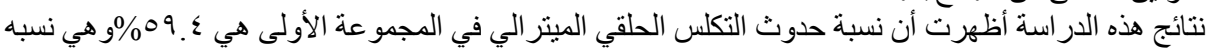

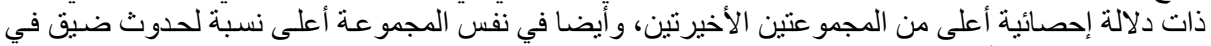

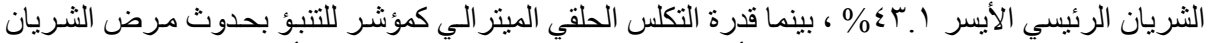

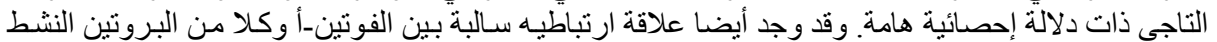

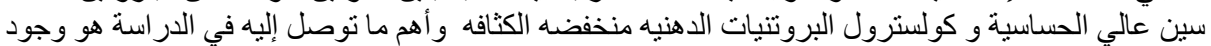

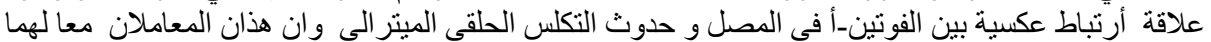
القدرة على التنبؤ بحدوث مرض السداد الثريان التاجي. 